\title{
COMPARISION OF LOCAL RETROFITTING OF R.C.FRAMES BY LINEAR STATIC METHOD FOR MODERATE AND SEVERE ZONE ON SOFT SOIL
}

\author{
Dhananjaiah.M ${ }^{1}$, B. Shivakumara Swamy $^{2}$, S. Vijaya ${ }^{3}$ \\ ${ }^{1}$ Post-Graduate Student, Civil Structural Engineering, Dr. Ambedkar Institute of Technology, Bengaluru, India \\ ${ }^{2}$ Professor and Head, Civil Engineering Department, Dr. Ambedkar Institute of Technology, Bengaluru, India \\ ${ }^{3}$ Professor, Civil Engineering Department, Dr. Ambedkar Institute of Technology, Bengaluru, India
}

\begin{abstract}
This paper presents on the comparison of Retrofitting/Rehabilitation of R.C.Frames for moderate and severe zone on soft soil, by using one of the standard finite element software ETABS 9.6.0by LINEAR STATIC METOD. In this case retrofitting is done for columns, where the additional load is added to the existing structure. It means the existing structure has constructed for (G+4), and the additional floors to $(G+6)$, according by using IS1893(PART-I)-2002for the earthquake design, when the over load is applied on the existing structure then the column get weakened and for this column retrofitting is done by R.C.JACKETTING method.it is also called as LOCAL RETROFITTING. ADDITIONAL LOAD concept is taken because, now a days generation population is more, and in the developing countries the purchasing the land is very difficult, because the land value cost very high, and even the land available also is very less in fully developed urban areas, Additional floors concept is more useful for residential as well as commercial purpose without any investment on land. Finally comparing it with moderate zone and severezone on soft soil with storey displacement,storey drift,base shear and percentage pf reinforcement.
\end{abstract}

Keywords: Linear static Analysis, base shear, storey displacement, storey drift, percentage of reinforcement, Retrofitting, confinement.

\section{INTRODUCTION}

There are numerous reasons may necessitate the need retrofit to existing structures. It may be the rehabilitation of a structure damaged by an earthquake, overloading or other causes, or the strengthening of an undamaged structure made necessary by considering in structural design or loading codes of practice. Earthquakes are the most common cause of damage structure to structures in earthquake-prone areas. Also, as the earthquake loading and design codes are subjected to more frequent revision than the rather established gravity-based codes, earthquake consideration becomes a main reason for the need to strengthen to the existing structures

\section{CONCEPT OF RETROFITTING}

Retrofitting means Restrengthening of the existing structure which is taken by one of the Rehabilitation method, usually damaged by overloading or by the seismic effects. Retrofitting is a technical method used in structural system of a building that improve the resistance to earthquake by increasing the strength, ductility and earthquake loads, strength of the building is generated from the structural dimensions, material shape and number of structural elements. Ductility of the structure frame is generated from the detailing, material used, degree of seismic Resistance etc.. earthquake load is generated from the site seismicity, mass of the structure, importants of buildings, degree of seismic resistance etc..
Due to different types of frames, it is not so easy to develop typical rules for retrofitting, each structure has different variety of approaches depending upon the structural deficiency. Hence engineers are needed to prepare and design the retrofitting approaches. In the design of retrofitting approach, the engineers must compute details by using the I.S.code. The results generated by adopting retrofitting techniques must completes with the minimum requirements on the I.S.codes such as deformation, detailing strength etc.

\subsection{Strengthening of R.C.C. Structure}

R.C.C Structure can be repairs and rehabilitation is a process for the existing structure is made to increase the probability that the structure will withstand for a long period of time and also against earthquake forces. This can be achieved by the addition of new structural elements, the strengthening of existing structural elements and/or the addition of base isolators, deterioration of concrete and corrosion of embedded reinforcement structure might make the reinforced concrete structure structurally deficient.

Before any work of retrofitting, the cause of damage must be identified as clearly as possible. This principle may seen self-evident but it is surprising how often it is decide with the result that further repairs have to be carried out within a short time.. The next step must be considering the objective 
of the repair, which will generally be to restore or enhance one or more of the following.

- Durability

- Structural strength

- Function

- Appearance

Of these four requirements restoration of durability is by for the most common in repair work. One must also consider whether the repair is to be permanent in temporary. Only after deciding on the most likely cause of damage should be less than $30 \%$ of structure, Whether it is likely to occur and the purpose of work should the method of repair to be chosen.

\section{There are 2 types of RETROFITTING STRATEGIES.}

\section{- Local Retrofit:}

Local retrofit strategies include local strengthening of beams, columns, slabs, beams to column or slab to column joints, walls and foundation. A scheme with such strategies tends to be the economical alternative when only few of the elements are deficient.

- Global Retrofit:

Global retrofit strategies, is also termed as structural level retrofit includes addition of new structural wall, steel braces, base isolaters etc..

\subsection{RC Jacketing:}

Reinforce concrete jacketing can be employed as a repair or strengthening scheme. Damage portions of the existing members should be repaired by technique of jacketing. There are two main purpose of jacketing of columns.

- Increase in the strength of columns in order to accomplished a strong column weak beam design.

- To improve the confinement column by the longitudinal steel of jacket mode continuous through the slab system are anchored with the foundation. It is achieved by passing the new longitudinal reinforcement through drilling holes drilled in the slab and by placing new concrete in the beam column joints as illustrated fig1.rehabilitaion sections are designed in the way so that the flexural strength of column should be greater than that of beam. Transverse steel above and below the joint has been provided with details, which consist of two L-shaped ties overlap diagonally in opposite corners because of the existing of the beam where bar benders have been used as shown in fig-1

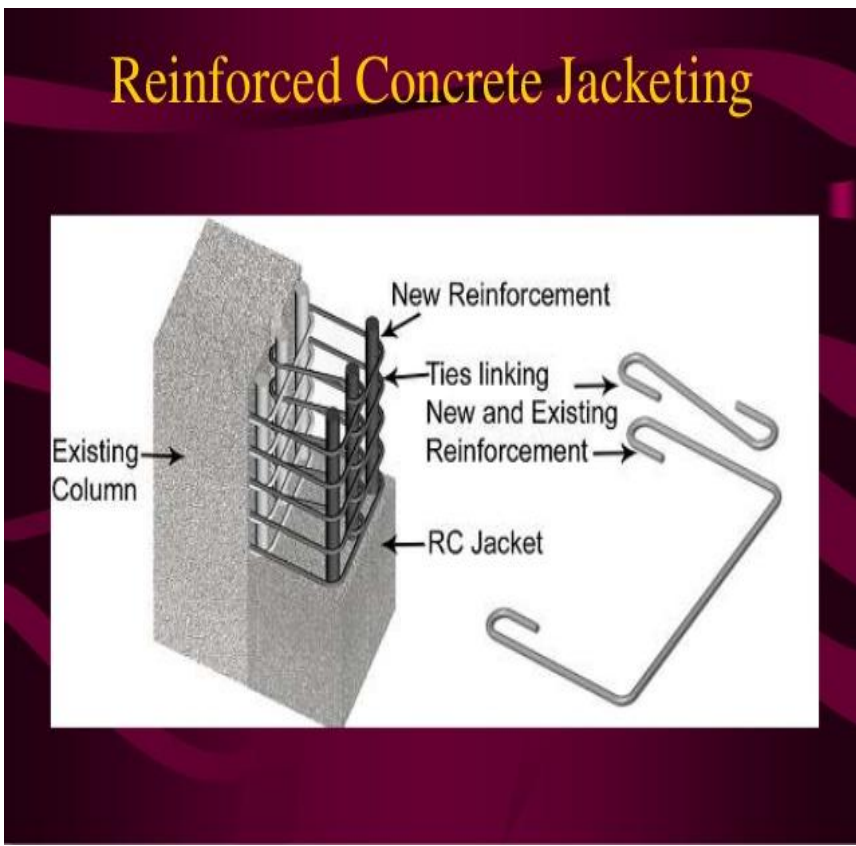

Fig-1 R.C.jacketting method.

\section{LINEAR STATIC ANALYSIS}

This linear static analysis is the simplest of all the analysis, which assumes a code, based calculation of base shear as the lateral horizontal force and is applied on the building. This is assumed to be equal to dynamic linear analysis. The calculated base shear on the basis of structural mass and fundamental period of vibration is then distributed to individual lateral load resisting elements depending upon the floor diaphragm action. All these calculation is based on IS1893:2002 (PART1) shall be determined by following expression.

Determination of Base shear: Design base shear $\left(\mathrm{V}_{\mathrm{B}}\right)$ along any principle direction shall be determined as,

$$
\mathrm{V}_{\mathrm{B}}=\mathrm{A}_{\mathrm{h}} \mathrm{W}
$$

Where, $\mathrm{W}=$ Seismic weight of the building

$A_{h}=$ Design horizontal seismic co-efficient for a structure given by.

$$
\mathrm{A}_{\mathrm{h}}=\left[\frac{\mathrm{Z}}{2}\right]\left[\frac{\mathrm{I}}{\mathrm{R}}\right]\left[\frac{\mathrm{S}_{\mathrm{a}}}{\mathrm{g}}\right] \leq\left[\frac{\mathrm{Z}}{2}\right]
$$

$\mathrm{Z}$ is the Zone factor for (MCE) Maximum Considered Earthquake [IS1893 (PART 1):2002, Table 2], denominator 2 is to reduce the MCE to design basis earthquake (DBE). This maximum intensity is fixed such that lifeline/critical structure remain functional and there is low probability of collapse for structures designed with the provision of code even after occurrence of higher intensity earthquake $I$ is the importance factor, depending upon the functional use of the structures, characterized by hazardous consequence of its failure, post-earthquake functional needs, historical value, or economic importance. 
$\mathrm{R}$ is the Response reduction factor, depending on the perceived seismic damage performance of the structure.

$\mathrm{Sa} / \mathrm{g}$ is the average response acceleration coefficient for rock or soil sites.

\section{MODELLING AND ANALYSIS}

The present study is carried out to understand the Technique of Retrofitting. The design of RC frame by linear method considering retrofitting points. The normal $\mathrm{RC}$ frame is desinged with some gravity load.FE model is developed using a standard software. Now extra load is applied due to this the joints may get weak. Finding the weak joints(column) and Rehabilitation technique is taken as this joints.After retrofitting is done. The $\mathrm{RC}$ frame is re-desinged.Plotting the curve for plain $\mathrm{n}$ retrofitting $\mathrm{RC}$ frame. Column numbering with plan of existing structure of zone 3 and zone 4 type- 3 soil as shown in fig-2. The plan is existed for $\mathrm{G}+4$ structure as shown in figure-3, and after two additional storey is considered, then the structure extended of $\mathrm{G}+6$ as shown in fig- 4

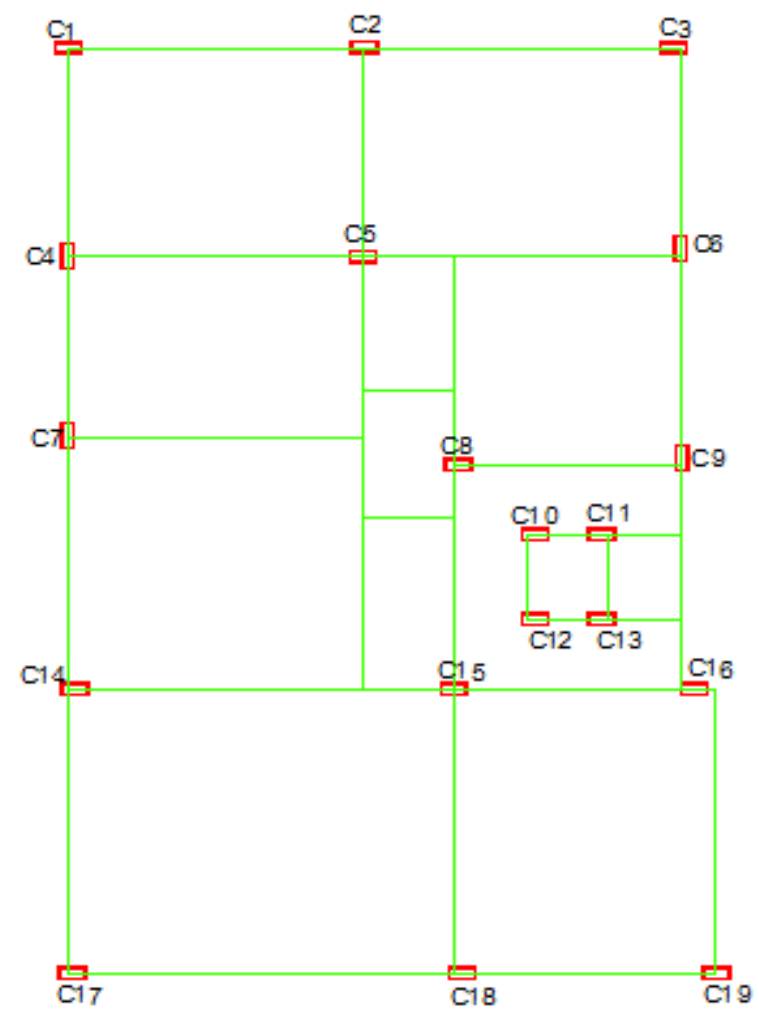

Fig-2: Plan of the existing structure with column numbering.

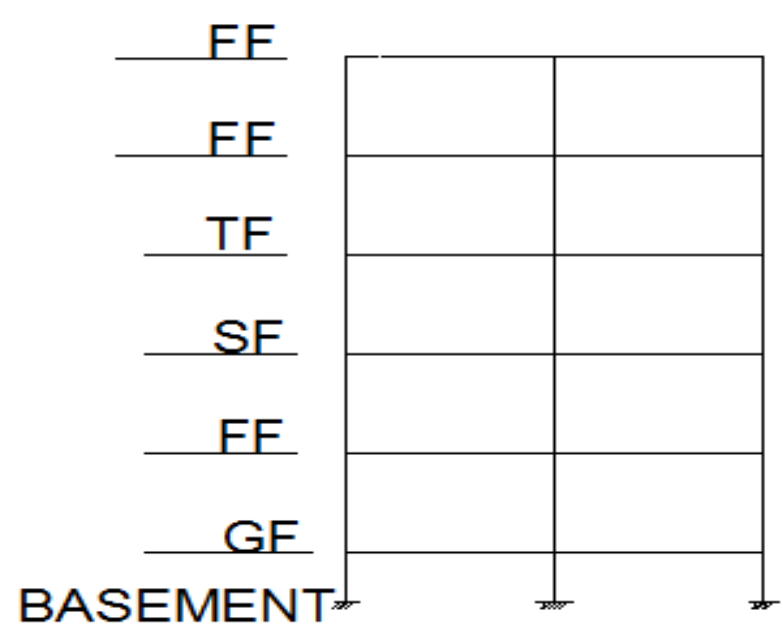

Fig-3 (G+4) Existing Structure

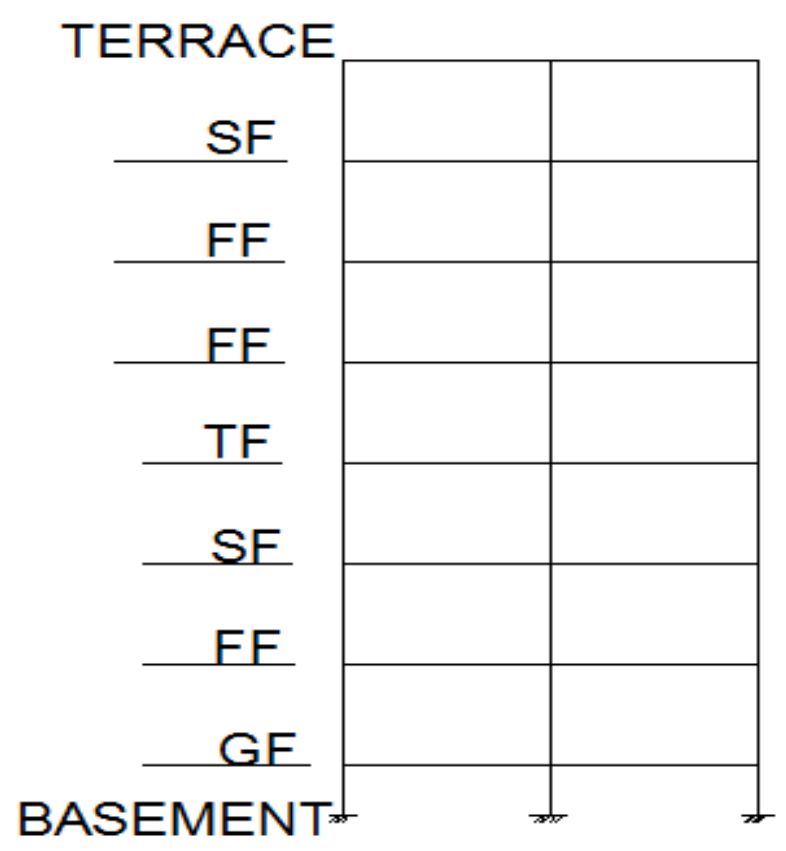

Fig-4 (G+6) Additional Load of 2 Storey’s

Table-1: Model data of the buildings

\begin{tabular}{|l|l|}
\hline Structure & OMRF \\
\hline NO. of stories & $\mathrm{G}+4$ \\
\hline Storey height & $3.00 \mathrm{~m}$ \\
\hline MATERIAL PROPERTIES & \\
\hline Grade of concrete & $\mathrm{M} 30$ \\
\hline Grade of steel & $\mathrm{Fe} 415$ \\
\hline MEMBER PROPERTIES & \\
\hline COLUMN SIZES & $200 \mathrm{X} 450$ \\
& $200 \mathrm{X} 600$ \\
\hline BEAM SIZES & $200 \mathrm{X} 450$ \\
\hline Thikness of slab & 125 \\
\hline LOAD INTENSITIES & \\
\hline DEAD LOAD & $1.0 \mathrm{KN} / \mathrm{m}^{2}$ \\
\hline LIVE LOAD & $2.75 \mathrm{KN} / \mathrm{m}^{2}$ \\
\hline FLOOR FINISH & $1.5 \mathrm{KN} / \mathrm{m}^{2}$ \\
\hline
\end{tabular}


EARTHQUAKE LOAD as per IS1893(part-I)-2002

SEISMIC ZONEIII \& IV

ZONE FACTOR,Z-

$0.16 \& 0.24$

Importance Factor,I-

1.00

Response reduction factor, $\mathrm{R}-\quad 3.00$

\section{Zone-4 Type-3}

Table-2: Before retrofitting column sizes

\begin{tabular}{|c|c|c|c|c|c|c|}
\hline $\begin{array}{l}\text { COLU } \\
M N \\
N O ' S\end{array}$ & $\begin{array}{l}B A S \\
E M E \\
N T\end{array}$ & $G F$ & $1 F$ & $2 F$ & $3 F$ & $4 F$ \\
\hline $\mathrm{C} 1$ & $\begin{array}{l}200^{*} \\
450\end{array}$ & $\begin{array}{l}200 * \\
450\end{array}$ & $\begin{array}{l}200 * \\
450\end{array}$ & $\begin{array}{l}200 * 4 \\
50\end{array}$ & $\begin{array}{l}200^{*} \\
450\end{array}$ & $\begin{array}{l}200 * \\
450\end{array}$ \\
\hline $\mathrm{C} 2, \mathrm{C} 3$ & $\begin{array}{l}200 * \\
600\end{array}$ & $\begin{array}{l}200 * \\
600\end{array}$ & $\begin{array}{l}200 * \\
600\end{array}$ & $\begin{array}{l}200 * 4 \\
50\end{array}$ & $\begin{array}{l}200^{*} \\
450\end{array}$ & $\begin{array}{l}200 * \\
450\end{array}$ \\
\hline $\mathrm{C} 4, \mathrm{C} 5$ & $\begin{array}{l}200 * \\
600\end{array}$ & $\begin{array}{l}200 * \\
600\end{array}$ & $\begin{array}{l}200 * \\
600\end{array}$ & $\begin{array}{l}200 * 6 \\
00\end{array}$ & $\begin{array}{l}200^{*} \\
450\end{array}$ & $\begin{array}{l}200 * \\
450\end{array}$ \\
\hline C6, C9 & $\begin{array}{l}200 * \\
600\end{array}$ & $\begin{array}{l}200 * \\
600\end{array}$ & $\begin{array}{l}200 * \\
600\end{array}$ & $\begin{array}{l}200 * 4 \\
50\end{array}$ & $\begin{array}{l}200^{*} \\
450\end{array}$ & $\begin{array}{l}200 * \\
450\end{array}$ \\
\hline $\mathrm{C} 7, \mathrm{C} 8$ & $\begin{array}{l}200^{*} \\
600\end{array}$ & $\begin{array}{l}200 * \\
600\end{array}$ & $\begin{array}{l}200 * \\
600\end{array}$ & $\begin{array}{l}200 * 6 \\
00\end{array}$ & $\begin{array}{l}200^{*} \\
450\end{array}$ & $\begin{array}{l}200 * \\
450\end{array}$ \\
\hline $\begin{array}{l}\text { C10,C1 } \\
1, \mathrm{C} 12, \\
\mathrm{C} 13, \mathrm{C} 1 \\
4\end{array}$ & $\begin{array}{l}200 * \\
450\end{array}$ & $\begin{array}{l}200 * \\
450\end{array}$ & $\begin{array}{l}200 * \\
450\end{array}$ & $\begin{array}{l}200 * 4 \\
50\end{array}$ & $\begin{array}{l}200^{*} \\
450\end{array}$ & $\begin{array}{l}200 * \\
450\end{array}$ \\
\hline $\begin{array}{l}\text { C15, } \\
\text { C17 }\end{array}$ & $\begin{array}{l}200 * \\
600\end{array}$ & $\begin{array}{l}200 * \\
600\end{array}$ & $\begin{array}{l}200 * \\
600\end{array}$ & $\begin{array}{l}200 * 6 \\
00\end{array}$ & $\begin{array}{l}200^{*} \\
450\end{array}$ & $\begin{array}{l}200 * \\
450\end{array}$ \\
\hline $\begin{array}{l}\text { C16, } \\
\text { C18 }\end{array}$ & $\begin{array}{l}200 * \\
600\end{array}$ & $\begin{array}{l}200 * \\
600\end{array}$ & $\begin{array}{l}200 * \\
600\end{array}$ & $\begin{array}{l}200 * 4 \\
50\end{array}$ & $\begin{array}{l}200^{*} \\
450\end{array}$ & $\begin{array}{l}200 * \\
450\end{array}$ \\
\hline C19 & $\begin{array}{l}200^{*} \\
450\end{array}$ & $\begin{array}{l}200 * \\
450\end{array}$ & $\begin{array}{l}200 * \\
450\end{array}$ & $\begin{array}{l}200 * 4 \\
50\end{array}$ & $\begin{array}{l}200^{*} \\
450\end{array}$ & $\begin{array}{l}200 * \\
450\end{array}$ \\
\hline
\end{tabular}

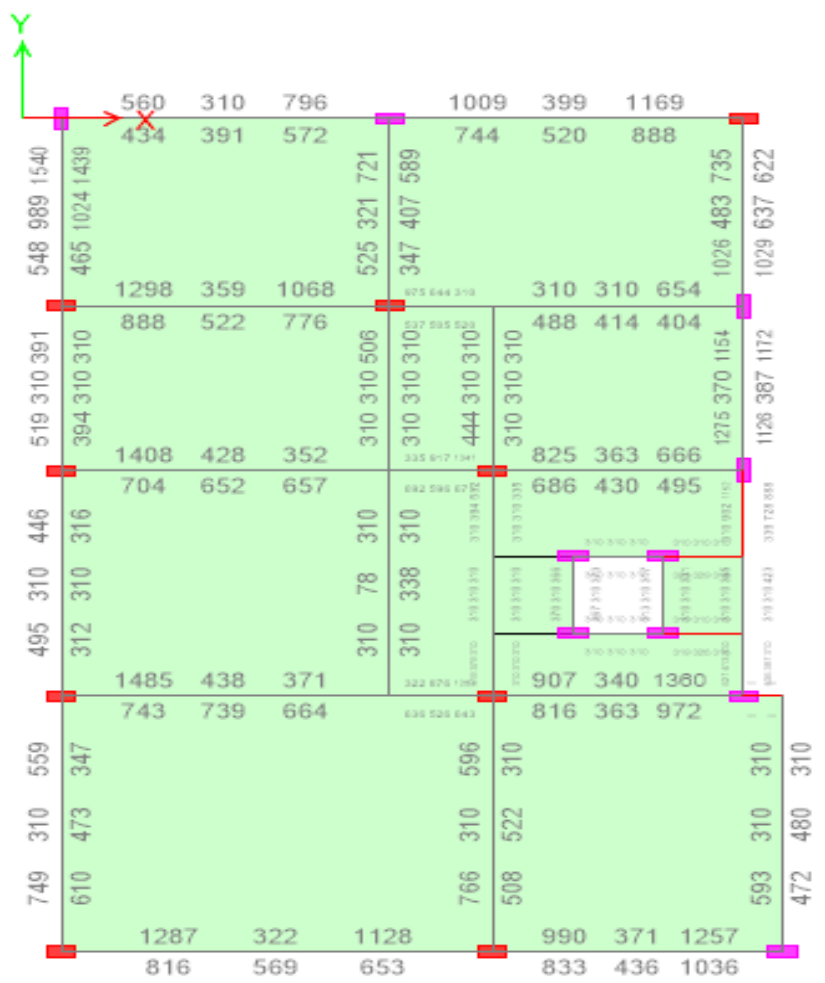

Fig-5

Additional floors are fifth and sixth floor.

\begin{tabular}{|l|l|l|}
\hline FIFTH FLOOR & C1 TO C19 & 200X450 \\
\hline SIXTH FLOOR & C1 TO C19 & $200 X 450$ \\
\hline
\end{tabular}

Table-3: After retrofitting column sizes with additional

\begin{tabular}{|c|c|c|c|c|c|c|}
\hline \multicolumn{7}{|c|}{ loads. } \\
\hline $\begin{array}{l}\text { COLU } \\
\text { MN } \\
\text { NO`S }\end{array}$ & $\begin{array}{l}\text { BAS } \\
\text { EM } \\
\text { ENT }\end{array}$ & GF & $1 \mathrm{~F}$ & $2 \mathrm{~F}$ & $3 \mathrm{~F}$ & $4 \mathrm{~F}$ \\
\hline $\begin{array}{l}\mathrm{C} 1, \mathrm{C} 2 \\
\text {,C3 }\end{array}$ & $\begin{array}{l}300 * \\
600\end{array}$ & $\begin{array}{l}300^{*} \\
600\end{array}$ & $\begin{array}{l}300 * \\
600\end{array}$ & $\begin{array}{l}300 * \\
600\end{array}$ & $\begin{array}{l}300^{*} \\
600\end{array}$ & $\begin{array}{l}200^{*} \\
450\end{array}$ \\
\hline $\begin{array}{ll}\text { C4 to } \\
\text { C9 }\end{array}$ & $\begin{array}{l}300^{*} \\
600\end{array}$ & $\begin{array}{l}300 * \\
600\end{array}$ & $\begin{array}{l}300 * \\
600\end{array}$ & $\begin{array}{l}300 * \\
600\end{array}$ & $\begin{array}{l}300^{*} \\
600\end{array}$ & $\begin{array}{l}300^{*} \\
600\end{array}$ \\
\hline $\begin{array}{l}\text { C10 } \\
\text { TO } \\
\text { C13 }\end{array}$ & $\begin{array}{l}200^{*} \\
450\end{array}$ & $\begin{array}{l}200^{*} \\
450\end{array}$ & $\begin{array}{l}200^{*} \\
450\end{array}$ & $\begin{array}{l}200^{*} \\
450\end{array}$ & $\begin{array}{l}200^{*} \\
450\end{array}$ & $\begin{array}{l}200^{*} \\
450\end{array}$ \\
\hline $\begin{array}{l}\text { C14 } \\
\text { TO } \\
\text { C19 }\end{array}$ & $\begin{array}{l}300^{*} \\
600\end{array}$ & $\begin{array}{l}300^{*} \\
600\end{array}$ & $\begin{array}{l}300 * \\
600\end{array}$ & $\begin{array}{l}300^{*} \\
600\end{array}$ & $\begin{array}{l}300^{*} \\
600\end{array}$ & $\begin{array}{l}300^{*} \\
600\end{array}$ \\
\hline
\end{tabular}

\section{Zone-3 Type-3}

Table-4: Before retrofitting column sizes.

\begin{tabular}{|c|c|c|c|c|c|c|}
\hline $\begin{array}{l}\text { COL } \\
\text { UMN } \\
\text { NO'S }\end{array}$ & $\begin{array}{l}\text { BAS } \\
\text { EME } \\
\text { NT }\end{array}$ & GF & $1 \mathrm{~F}$ & $2 \mathrm{~F}$ & $3 \mathrm{~F}$ & $4 \mathrm{~F}$ \\
\hline $\mathrm{C} 1$ & $200 *$ & $200 *$ & $200 *$ & $200 * 4$ & $200 *$ & $200^{*}$ \\
\hline $\begin{array}{l}\text { TO } \\
\text { C19 }\end{array}$ & 450 & 450 & 450 & 50 & 450 & 450 \\
\hline
\end{tabular}




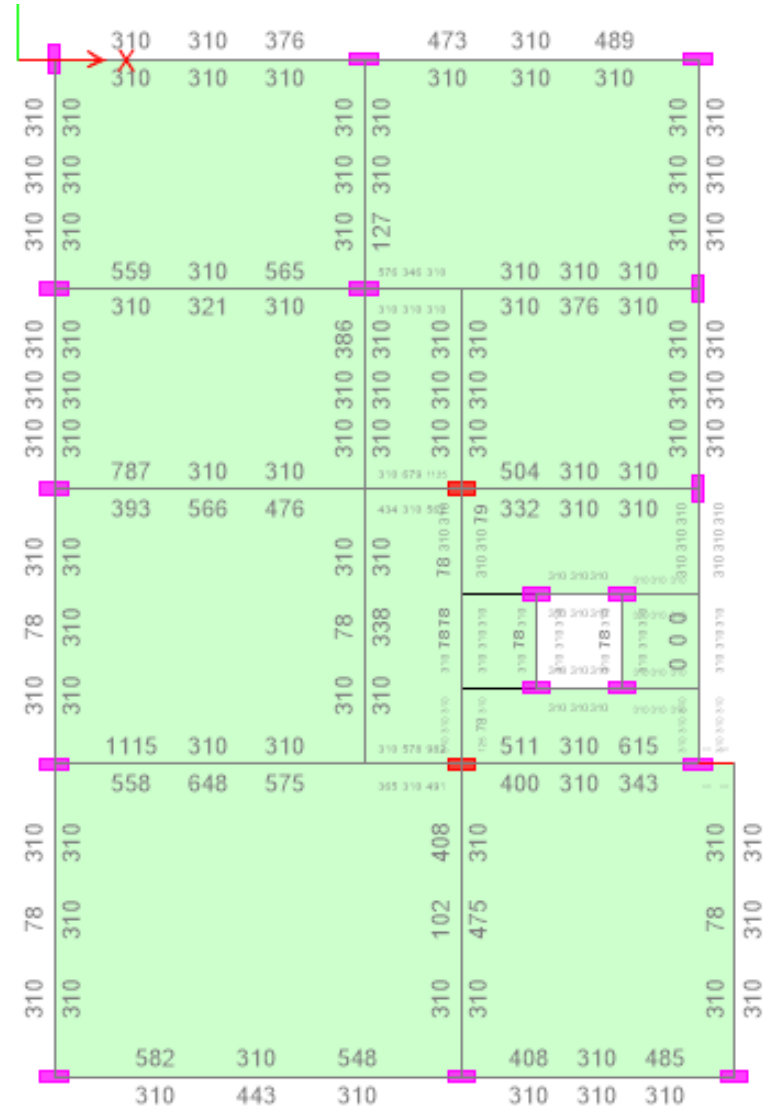

Fig-6

Additional floors are fifth and sixth floor

\begin{tabular}{|l|l|l|}
\hline FIFTH FLOOR & C1 TO C19 & 200X450 \\
\hline SIXTH FLOOR & C1 TO C19 & $200 X 450$ \\
\hline
\end{tabular}

Table-5: After retrofitting column sizes with additional loading.

\begin{tabular}{|c|c|c|c|c|c|c|}
\hline $\begin{array}{l}\mathrm{COL} \\
\mathrm{UMN} \\
\mathrm{NO} \cdot \mathrm{S}\end{array}$ & $\begin{array}{l}\text { BAS } \\
\text { EME } \\
\text { NT }\end{array}$ & GF & $1 \mathrm{~F}$ & $2 \mathrm{~F}$ & $3 F$ & $4 \mathrm{~F}$ \\
\hline $\begin{array}{l}\mathrm{C} 1 \\
\text { TO } \\
\mathrm{C} 4\end{array}$ & $\begin{array}{l}200 * \\
450\end{array}$ & $\begin{array}{l}200 * \\
450\end{array}$ & $\begin{array}{l}200^{*} \\
450\end{array}$ & $\begin{array}{l}200^{*} \\
450\end{array}$ & $\begin{array}{l}200^{*} \\
450\end{array}$ & $\begin{array}{l}200^{*} \\
450\end{array}$ \\
\hline C5 & $\begin{array}{l}300 * \\
600\end{array}$ & $\begin{array}{l}300 * \\
600\end{array}$ & $\begin{array}{l}200 * \\
450\end{array}$ & $\begin{array}{l}200^{*} \\
450\end{array}$ & $\begin{array}{l}200^{*} \\
450\end{array}$ & $\begin{array}{l}200^{*} \\
450\end{array}$ \\
\hline $\begin{array}{l}\text { C6, } \\
\text { C7 }\end{array}$ & $\begin{array}{l}200^{*} \\
450\end{array}$ & $\begin{array}{l}200 * \\
450\end{array}$ & $\begin{array}{l}200 * \\
450\end{array}$ & $\begin{array}{l}200^{*} \\
450\end{array}$ & $\begin{array}{l}200^{*} \\
450\end{array}$ & $\begin{array}{l}200^{*} \\
450\end{array}$ \\
\hline $\begin{array}{l}\text { C9 } \\
\text { TO } \\
\text { C13 }\end{array}$ & $\begin{array}{l}200 * \\
450\end{array}$ & $\begin{array}{l}200 * \\
450\end{array}$ & $\begin{array}{l}200^{*} \\
450\end{array}$ & $\begin{array}{l}200^{*} \\
450\end{array}$ & $\begin{array}{l}200^{*} \\
450\end{array}$ & $\begin{array}{l}200^{*} \\
450\end{array}$ \\
\hline C14 & $\begin{array}{l}300 * \\
600\end{array}$ & $\begin{array}{l}300 * \\
600\end{array}$ & $\begin{array}{l}300 * \\
600\end{array}$ & $\begin{array}{l}200 * \\
450\end{array}$ & $\begin{array}{l}200^{*} \\
450\end{array}$ & $\begin{array}{l}200^{*} \\
450\end{array}$ \\
\hline C15 & $\begin{array}{l}300 * \\
600\end{array}$ & $\begin{array}{l}300 * \\
600\end{array}$ & $\begin{array}{l}300 * \\
600\end{array}$ & $\begin{array}{l}300 * \\
600\end{array}$ & $\begin{array}{l}200 * \\
450\end{array}$ & $\begin{array}{l}200 * \\
450\end{array}$ \\
\hline $\begin{array}{l}\text { C16 } \\
\text { TO } \\
\text { C19 }\end{array}$ & $\begin{array}{l}200 * \\
450\end{array}$ & $\begin{array}{l}200 * \\
450\end{array}$ & $\begin{array}{l}200^{*} \\
450\end{array}$ & $\begin{array}{l}200^{*} \\
450\end{array}$ & $\begin{array}{l}200^{*} \\
450\end{array}$ & $\begin{array}{l}200^{*} \\
450\end{array}$ \\
\hline
\end{tabular}

\section{RESULTS AND DISCUSSION}

This study is concentrated on retrofitting of reinforced concrete frames. The proposed reinforced concrete frame is located in zone- 3 and zone- 4 prone areas and is designed and analysis is done by using ETABS software and comparing for both the zone type of TYPE-III soil.

Shows column has got lesser strength to withstand the additional floor loads, so to increase the strength, the column size should increase which means retrofitting to column is done by R.C.Jacketing method,as shown in fig-1.

An existing structure $(\mathrm{G}+4)$, basement to ground floor $1.5 \mathrm{~m}$ height and typical floor is $3.0 \mathrm{~m}$ height, as shown in fig- 3 .

After additional load is added, the structure is extended from $(\mathrm{G}+4)$ to $(\mathrm{G}+6)$, basement to ground floor $1.5 \mathrm{~m}$ height and typical floor is $3.0 \mathrm{~m}$ height, as shown in fig-4. column failures when additional floor load is applied on existing structure, and to failure columns retrofitting is done, as shown in fig-5 \& 7 .

NOTE: read colour columns are failure columns.

\section{Zone-4 Type-3}

\section{Storey Displacement}

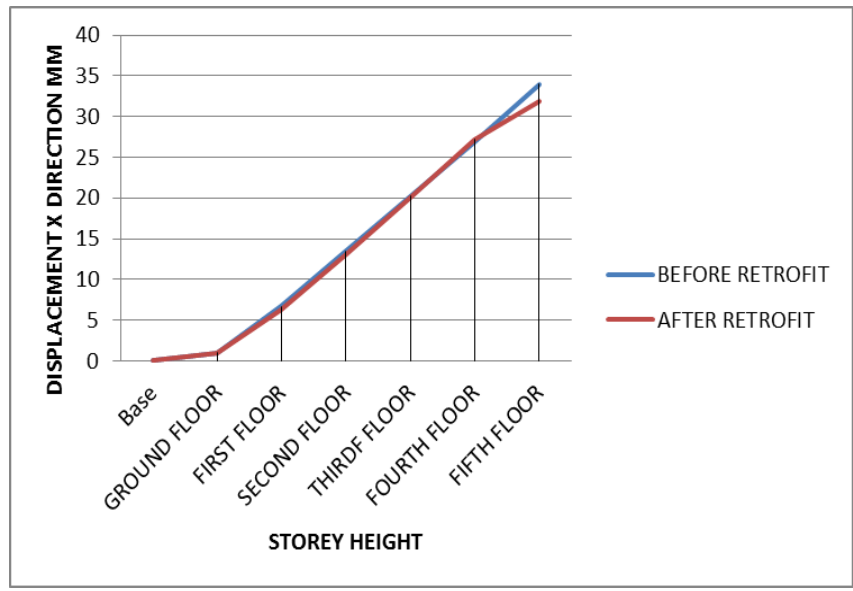

Fig-7

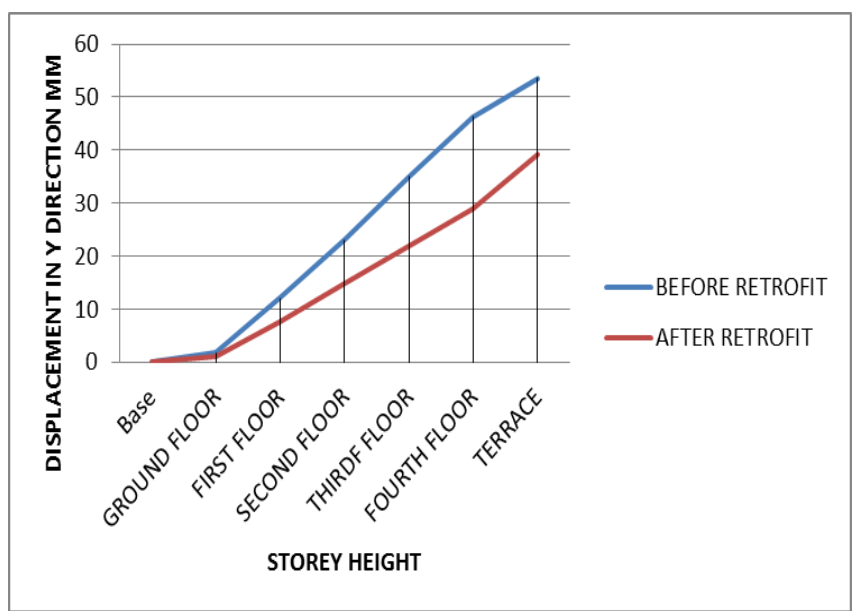

Fig-8 
Fig-7 and 8 shown storey displacement in ' $\mathrm{X}$ ' and ' $\mathrm{Y}$ ' direction by linear static method in zone-4, after retrofitting storey displacements will decrease compare to before retrofitting.

\section{Zone-3 Type-3}

\section{Storey Displacement}

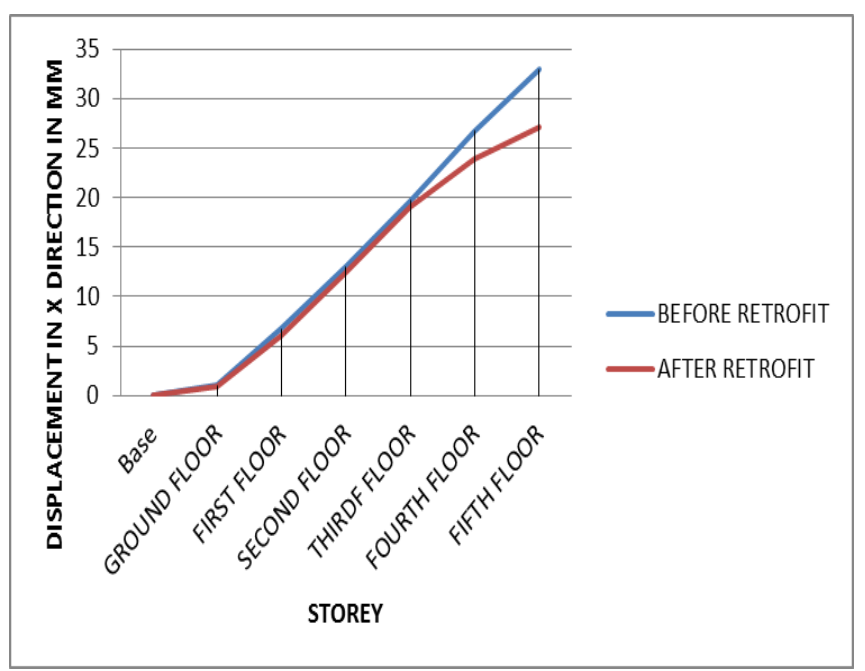

Fig-9

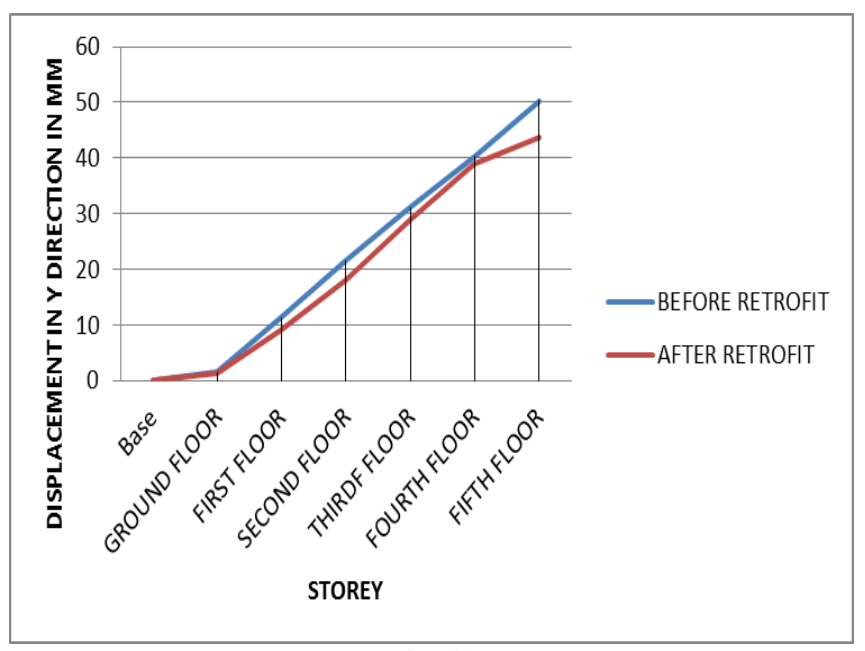

Fig-10

Fig-9 and 10: shows storey displacement in ' $\mathrm{X}$ ' and ' $\mathrm{Y}$ ' direction by linear static method in zone-3, after retrofitting storey displacements will decrease compare to before retrofitting.

\section{Zone-4 Type-3}

\section{Storey Drift}

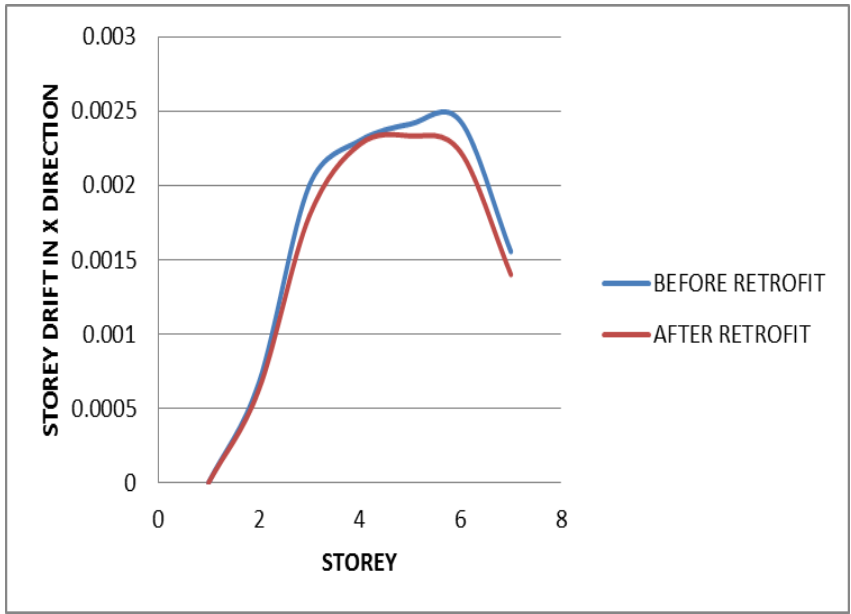

Fig-11

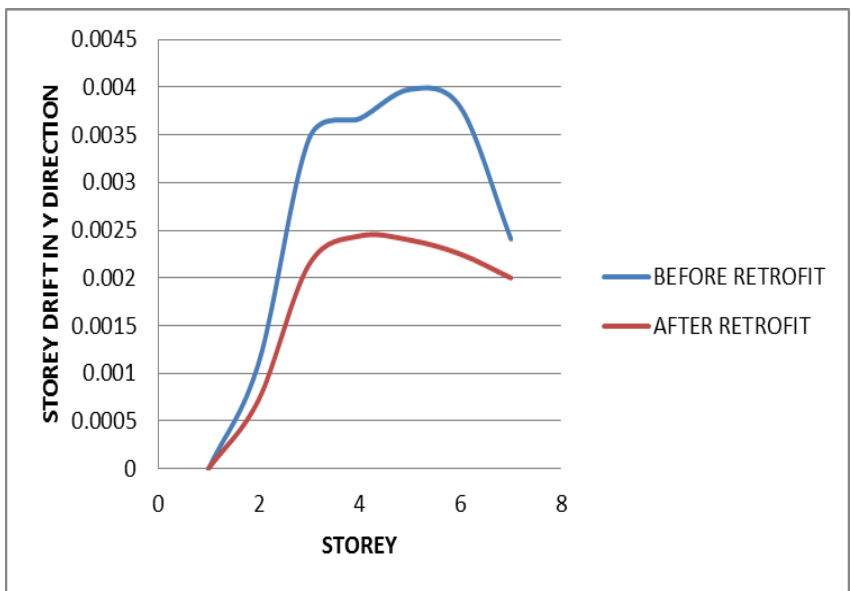

Fig-12

Fig-11 and 12: shows storey displacement in ' $\mathrm{X}$ ' and ' $\mathrm{Y}$ ' direction by linear static method in zone-4, after retrofitting storey displacements will decrease compare to before retrofitting.

\section{Zone-3 Type-3}

\section{Storey Drift}

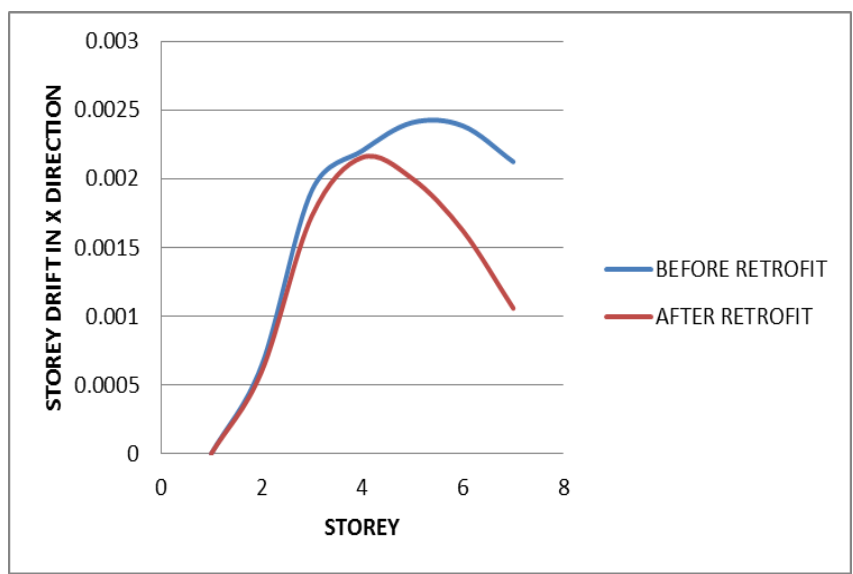

Fig-13 


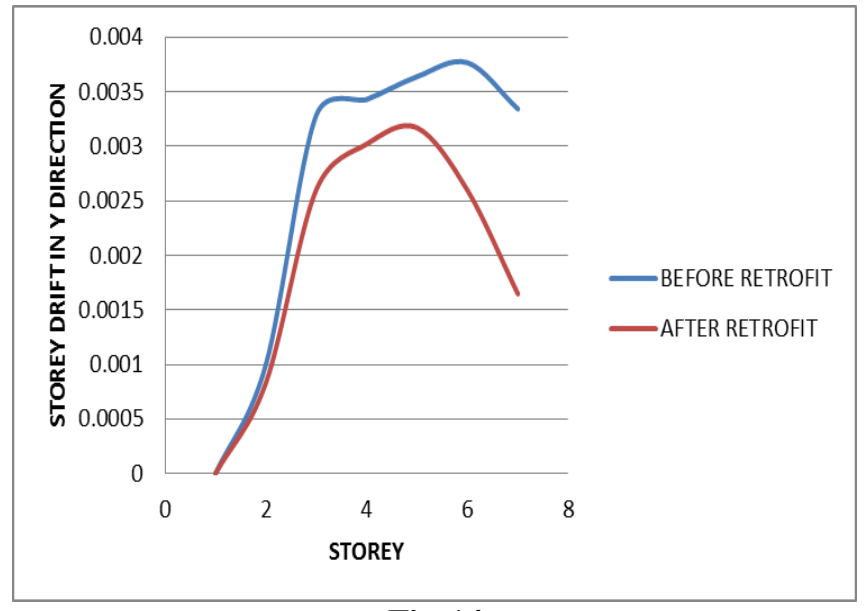

Fig-14

Fig-13 and 14 shows storey drift in ' $\mathrm{X}$ ' and ' $\mathrm{Y}$ ' direction by linear static method in zone-3, after retrofitting storey displacements will decrease compare to before retrofitting.

\section{Zone-4 Type}

\section{Base Shear}

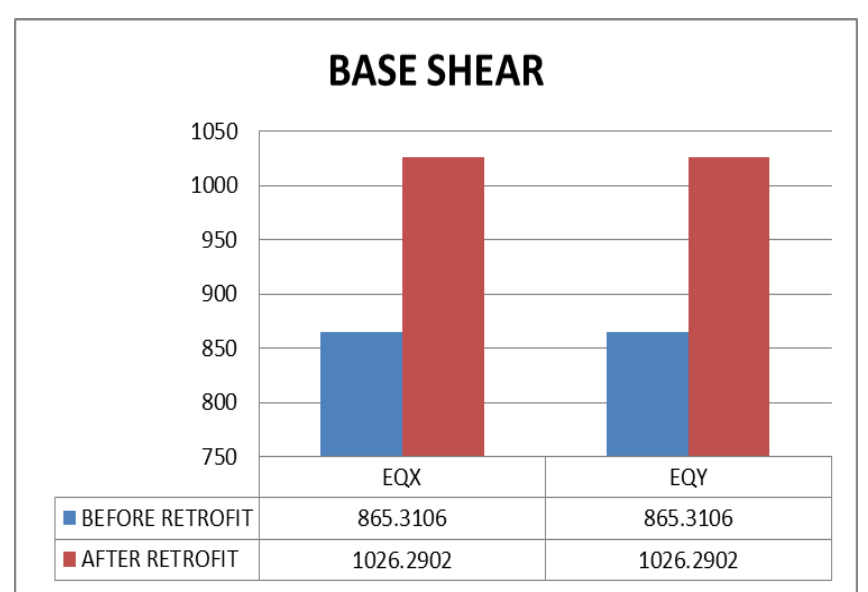

Fig-15:Base shear capacity is increased after retrofitting compare to before retrofit.

\section{Zone-3 Type-3}

\section{Base Shear}

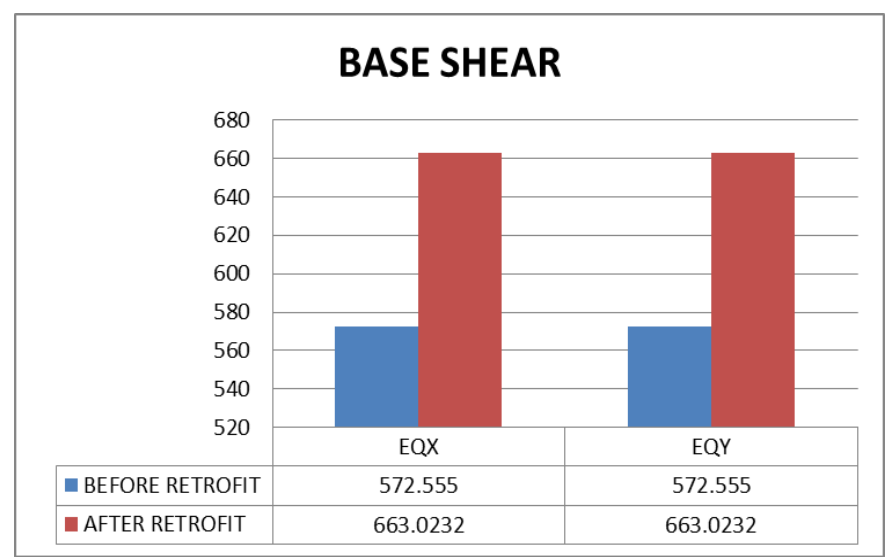

Fig-16: Base shear capacity is increased after retrofitting compare to before retrofit.

\section{Zone-4 Type-3}

TABLE-6: Percentage of Additional reinforcement after retrofitting.

\begin{tabular}{|l|l|l|l|}
\hline FLOORS & $\begin{array}{l}\text { NO OF } \\
\text { COLUMNS }\end{array}$ & $\begin{array}{l}\text { \% OF } \\
\text { EACH } \\
\text { COLUMN }\end{array}$ & $\begin{array}{l}\text { TOTAL } \\
\text { \% OF } \\
\text { EACH } \\
\text { FLOOR }\end{array}$ \\
\hline $\begin{array}{l}\text { FOURTH } \\
\text { FLOOR }\end{array}$ & 12 & 27 & 324 \\
\hline $\begin{array}{l}\text { THIRD } \\
\text { FLOOR }\end{array}$ & 15 & 27 & 405 \\
\hline $\begin{array}{l}\text { SECOND } \\
\text { FLOOR }\end{array}$ & 15 & 27 & 405 \\
\hline $\begin{array}{l}\text { FIRST } \\
\text { FLOOR }\end{array}$ & 15 & 27 & 405 \\
\hline $\begin{array}{l}\text { GROUND } \\
\text { FLOOR }\end{array}$ & 15 & 27 & 405 \\
\hline BASEMENT & 15 & 27 & 405 \\
\hline
\end{tabular}

TOTAL \% OF REINFORCEMENT $=2349 \%$

\section{Zone-3 Type-3}

TABLE-7: Percentage of Additional Reinforcement after

\begin{tabular}{|l|l|l|l|}
\hline FLOORS & $\begin{array}{l}\text { NO Retrofitting } \\
\text { COLUMNS }\end{array}$ & $\begin{array}{l}\text { \% } \\
\text { EACH OF } \\
\text { COLUMN }\end{array}$ & $\begin{array}{l}\text { TOTAL } \\
\text { \% OF } \\
\text { EACH } \\
\text { FLOOR }\end{array}$ \\
\hline $\begin{array}{l}\text { SECOND } \\
\text { FLOOR }\end{array}$ & 1 & 33 & 33 \\
\hline $\begin{array}{l}\text { FIRST } \\
\text { FLOOR }\end{array}$ & 3 & 33 & 99 \\
\hline $\begin{array}{l}\text { GROUND } \\
\text { FLOOR }\end{array}$ & 4 & 33 & 132 \\
\hline BASEMENT & 4 & 33 & 132 \\
\hline
\end{tabular}

TOTAL \% OF REINFORCEMENT $=396 \%$

\section{CONCLUSION}

This study is concentrated on retrofitting of reinforced concrete frames. The proposed reinforced concrete frame is located in zone- 3 and zone- 4 prone areas and is designed and analysis is done by using ETABS software and comparing for both the zone type of TYPE-III soil. Retrofitting attempt is made on weakening points of structure(COLUMN RETROFITTING), when additional floor is constructed above existing floors. According earthquake code book IS 1893(PART-I) 2002, the analysis is made on existing building for MODERATE ZONE and SEVERE ZONE and weak soil (TYPE-III).As above study G+4(existing structure) and 2storeys additionally added, so this the existing structure column has get weaken, so this column retrofitting technique is taken to regain its strength on existing columns. 
The following are the conclusion drawn on the basis of result obtained.

Storey displacement, is decrease displacement as storey height increase, displacement curve before and after retrofitting for two different zones.

Base shear is Increased for different loading as before and after retrofitting for two different zones.

Storey drift is decrease as height increase as retrofitting is done for two different zones.

Percentage of reinforcement/column sizes increase after retrofitting is done for existing structure of two different zones.

\section{REFERENCES}

[1] IS 1893(PART-1)-2002, “criteria of earthquake resistance design of structures, Bureau of Indian standards", NEW DELHI.

[2] FEMA 356(2000) "prestandard and commentary for the seismic rehabilitation of buildings" Ameriacan society of civil engineers, USA.

[3] IS 13935:1993 "Indian standard for reapair and seismic strengthening of building guide lines" Beaureau of indian standards, new delhi.

[4] ACT 40(1996), "Seismic evaluation and retrofit of concrete building vol-1" applied technology council, USA.

[5] IS 13920:1993 "Indian standard code for practice Ductile Detailing of Reinforced concrete structure subjected to seismic force" Bureau of Indian standards, new delhi.

[6] EL-Amoury, T and Ghobarah,A(2002), "seismic Rehabilitation of beam-column using GERP Sheets", Engineering Structures, Elsevier Science Ltd., November, vol-24 No.11, pp.1397-140. 